\title{
Hybrid forms of living: Bangrakam, Phitsanuloke, Thailand
}

\author{
W. Pittungnapoo \\ Faculty of Architecture, Naresuan University, Phitsanulok, Thailand
}

\begin{abstract}
Bangrakam is one of the nine districts of Phitsanulok province, which is located in the lower north region of Thailand, $377 \mathrm{~km}$ from Bangkok. The district is located in the southwest of Phitsanulok, or $17 \mathrm{~km}$ from the city center. Bangrakam is a small town settled on the Yom River and is wholly located in the Yom River basin. The central part of Bangrakam is dominated by the reservoir, resulting in inundation for a few months every year during the rainy season. Interestingly, flooding has surprisingly not been seen as a problem for many or most Bangrakam dwellers. Amazingly, people have adjusted their houses and livelihood to fit or coexist with water in friendly ways. During the flooding season people go fishing and gain a lot of income from fishery products. Hybrid ways of living make Bangrakam a unique cultural landscape. Wet architecture, water-based domestic space, wet cultural landscape, water-based livelihoods, and other water-based elements are evidence illustrating how the residents live in harmony with water and survive flooding in more friendly ways. This article suggests that learning from the Bangrakam case can remind Thais to be concerned with and understand their own indigenous wisdoms more. More specifically, without appropriate adaptability, particularly in water land use planning and aquatic zone management, it will be far more difficult to survive the future in which water dramatically dominates our planet.
\end{abstract}

Keywords: hybrid ways of living, floating houses, stilt houses, flooding, Bangrakam, Phitsanulok, Thailand.

\section{Introduction}

Bangrakam is one of the nine districts of Phitsanulok province, which is located in the lower north region of Thailand, $377 \mathrm{~km}$ from Bangkok. The district is 
located in the southwest of Phitsanulok, or $17 \mathrm{~km}$ from the city center. The total area of Bangrakam is about 992,043 square kilometers and it consists of 11 subdistricts [1]; however, the term "Bangrakam" mentioned in this paper refers to Bangrakam sub-district, just a small town which was settled on the right bank of the Yom River. Owing to the fact that almost the whole area is situated on the river plain, as a result it is faced with seasonal flooding for a few months every year. However, flooding has surprisingly not been any problem for Bangrakam inhabitants. Amazingly, people have adjusted their houses and livelihood to fit or coexist with water in friendly ways. During the flooding season the people go fishing and preserve fish for selling; undoubtedly, Bangrakam people can generate high incomes from flooding. Canoes, fishing tools, and elevated storage space are examples of survival evidence. Floating houses and stilt houses with unique domestic space have been designed for living with water during the rainy season. With enough natural nutrients deposited during flooding, Bangrakam people then return to grow rice and crops after the flood had receded, as they usually do during the dry season. Learning from the Bangrakam case, interestingly, it has been revealed that flooding has not proven to be harmful to the inhabitants; they see flooding as a familiar friend and learn how to live together with water rather than seeing it as a disaster against their livelihoods.

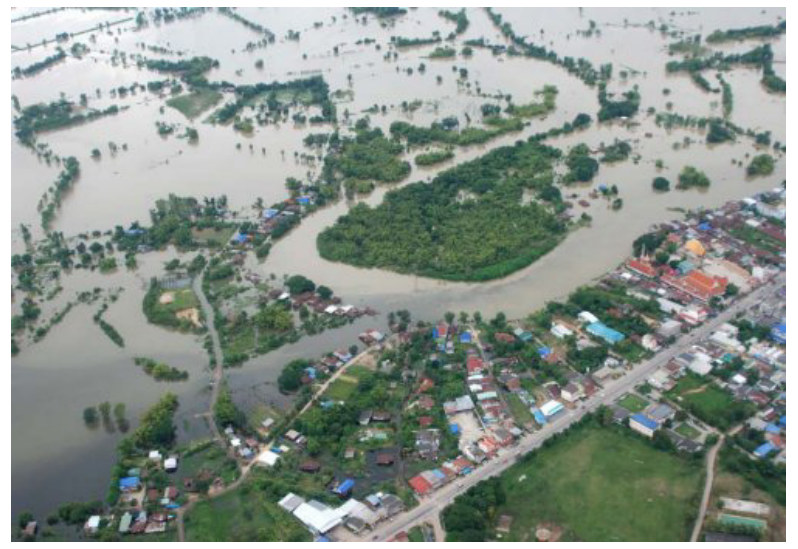

Figure 1: $\quad$ An aerial map of Bangrakam [3].

\subsection{Geographic features}

Bangrakam is a small town settled on the Yom River Plain in Phitsanulok Province. The total area is 135.58 square kilometres which is mainly agricultural land, while 6 percent of the total area is residential areas, and the rest are other uses. The site's gradient slopes from north to south. The central part of Bangrakam is occupied by natural reservoirs and most of the land is crisscrossed by the Yom River. These make Bangrakam a good place for cultivation and it also is usually flooded for a few months during the rainy season (from late August to late October); however, Bangrakam always experiences drought during the dry season [1]. 


\subsection{Climatic situation}

Phitsanulok is a warm and humid city with the temperature averaging $35-43^{\circ} \mathrm{C}$. The winter or cool season lasts from November to February. The dry season is from March to June. The rainy season is from June to October [1].

\subsection{Demography figures}

A small town, the total population of Bangrakam in 2010 was 12,151, consisting of 5,817 males and 6,334 females. The number of households is 3,758 with a density of 94 people $/ \mathrm{km}^{2}$. Most of Bangrakam's population earn a living as rice growers and farmers, followed by traders/merchants and other employees [1].

\section{Typologies of Bangrakam's houses}

Data from fieldwork shows that there are three main types of houses found in Bangrakam sub-district. Starting from the river and moving towards the waterfront area and closer to the land, we can see how Bangrakam people live and adjust their houses to attempt to live in harmony with the water as well as with nature.

\subsection{Floating or raft houses}

The first unique form of living is floating houses or raft houses, known as "Ruan Pae" by Thais. This type can be found on the river zone; however, there are just a few left on the Yom River. The house is built as a tiny hut made from timbers while the floors are laid on bamboos which make it able to float. Undoubtedly, flooding is unlikely to be any problem for these rafts (Pittungnapoo [2]).

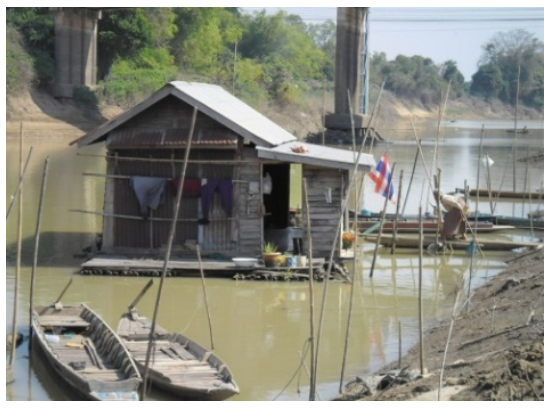

Figure 2: Floating house on the Yom River, Bangrakam.

However, this form of living has a limitation in terms of using the public water supply, as all raft dwellers use water from the Yom River directly for their daily chores. Water sanitation has been another problem for raft habitat, because most of the old rafts were built with no hygienic toilets. However, ready-made sludge and storage tanks could be attached with proper toilets for new rafts, as shown in Figure 3 below. 

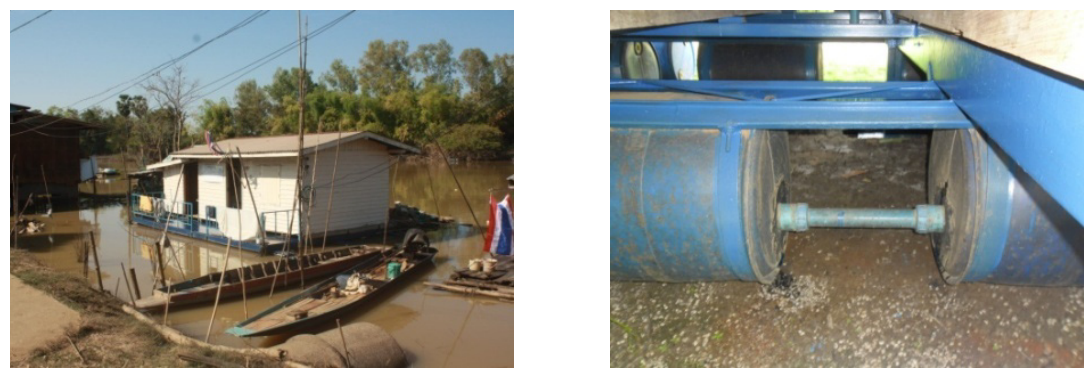

Figure 3: A new raft was rebuilt with sludge and storage tanks.

\subsection{Highly elevated on stilt houses}

Regarding the waterfront zone, the second type of house is built and elevated on very high concrete columns, about 3 to 5 metres above the ground. These make Bangrakam a unique living place. Over the previous decade, people had to elevate their houses higher and higher to avoid flooding due to a rising level of flood water. During the wet season the high elevated structure allows flood water to flow through; therefore, flooding no longer damages their living space. During the dry season, on the other hand, people can use space underneath the floor to carry on their daily chores as usual.
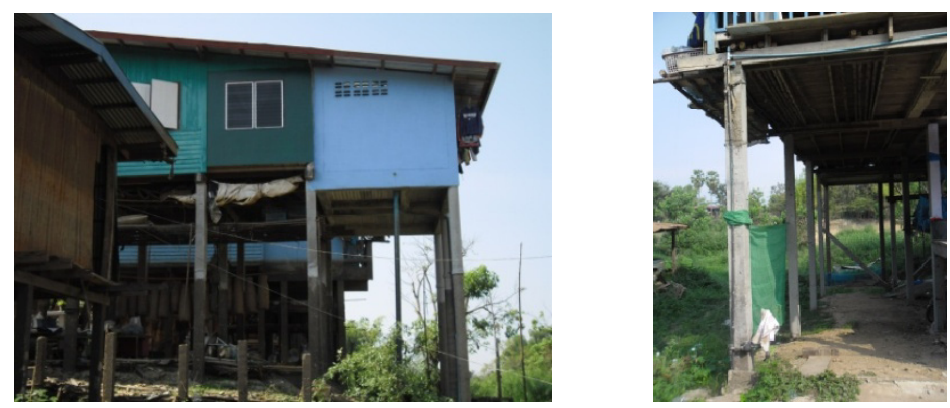

Figure 4: Left: highly elevated stilt house near the Yom River, Bangrakam. Right: the water supply pipes were attached to columns.

This form of living has no problem with sanitary treatment systems and all high stilt houses were supplied with public water provided by Bangrakam District Municipality. Almost all toilets in these houses were built on the first floor; therefore, most of the households can use toilets as usual during the flooding. However, toilets which were built on the ground floor were flooded and cannot be used during the wet season. 

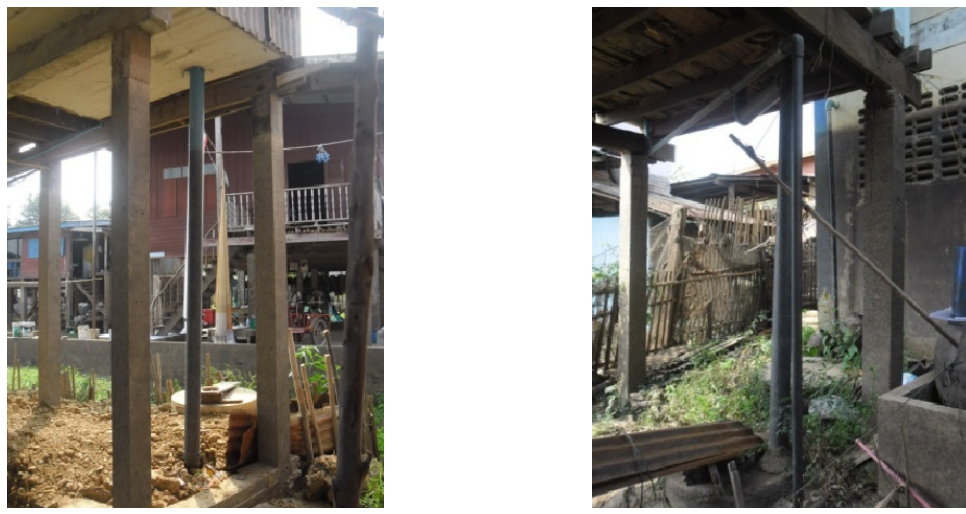

Figure 5: $\quad$ Sludge pipes were discharged into sludge and storage tanks which were located into ground and only tops were emerged over the ground.

\subsection{Low elevated stilt houses}

This type of house can be found far away from the river, which is at less risk to flooding. The stilts can be 1.50- 3.00 metres in height. The low elevated wooden stilt houses were typical houses located along the Yom River; however, according to the rising flood level, people had to elevate their houses on higher columns.

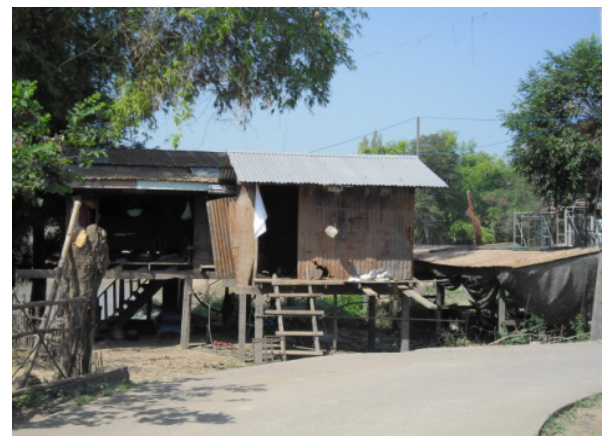

Figure 6: Low stilt house, Bangrakam.

Although public water and proper toilets are present in almost all low stilt houses, many of them will become flooded, thus making for difficulty in using toilets during the wet season. Many households revealed that they had to use or rent toilets from their neighbours during the flooding season. 


\subsection{Concrete houses}

This type of house was built in several forms, a single story, two stories, and as shop houses. This kind of building was mainly found on upper land and most of them were clustered along the roads. However, there are some concrete houses located near the River; undoubtedly, they are severely damaged by flooding every year and people have to repaint their house after the water is flushed away.
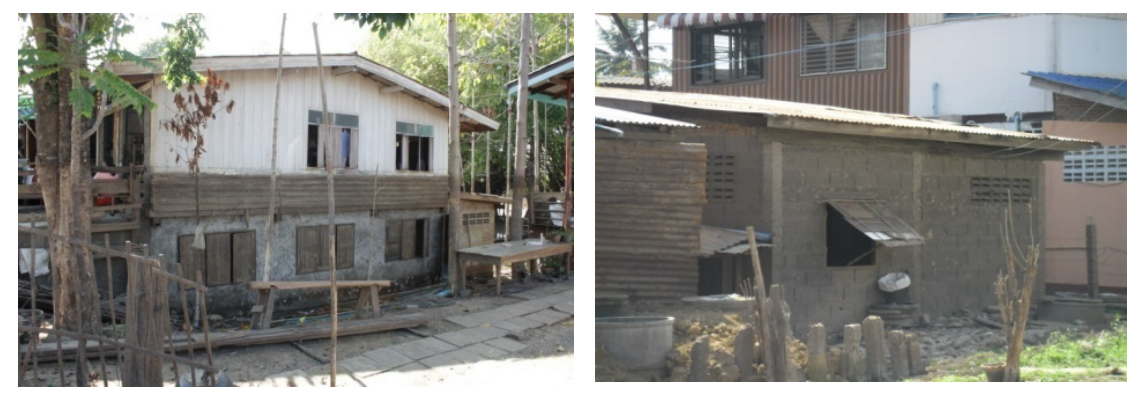

Figure 7: Concrete houses in Bangrakam.

Concrete houses have no problem with sanitary treatment systems and they were supplied with public water; however, all of these households' toilets which were built on the ground floor become inundated and unable to be used during the flooding.

\section{Hybrid ways of living}

As already mentioned, the Bangrakam people living on the Yom River Basin have learned how to live with seasonal flooding in friendly and desirable ways, as they have illustrated their being in harmony with nature, particularly in a water-based environment. There are several aspects reflecting their hybrid ways of living, as presented in the Table 1 .

\subsection{Water-based housing characteristics}

Two types of houses can be represented as wet architecture; the first is floating houses; the second is stilt houses with high columns. The former can be found on the Yom River, which was mostly built from timber and light materials. The house was small and the interior space was compact. The whole structure was laid on cottons of bamboos that make it freely floatable on water. The latter form is the stilt house which was built high above the ground. Many households had to elevate their houses to sit on higher stilts in order to live without being flooded. These two typologies have represented the local wisdom of Bangrakam people who can survive and prosper in the face of flooding. 
Table 1: $\quad$ Hybrid ways of living.

\begin{tabular}{|c|c|c|}
\hline \multirow{2}{*}{ Local Wisdom } & Hybrid Ways of Living \\
\hline \multirow{3}{*}{$\begin{array}{c}\text { Housing } \\
\text { characteristics }\end{array}$} & Derrestrial floating houses & Wet Season \\
\cline { 2 - 3 } & Terrestrial stilt houses & Wet stilt houses \\
\hline Domestic space & Ground storage space & Elevated storage space \\
\cline { 2 - 3 } & Ground floor usage & Elevated floor \\
\cline { 2 - 3 } & Roof & Storage roof \\
\cline { 2 - 3 } & Road-based parking & Canoes' moor \\
\hline \multirow{3}{*}{$\begin{array}{c}\text { Cultural } \\
\text { landscape }\end{array}$} & Non-water elements & Water-based elements \\
\cline { 2 - 3 } & Dry landscape & Wet landscape/ water plants \\
\cline { 2 - 3 } & Terrestrial habitants & Water people \\
\cline { 2 - 3 } & Motorbikes, car usage & Canoe usage \\
\cline { 2 - 3 } & Cropping tools & Fishery tools \\
\cline { 2 - 3 } & Ground-based activities & Water-based activities \\
\hline Livelihood & Rice growing & Fishery \\
\hline
\end{tabular}

\subsection{Hybrid domestic space}

Bangrakam people have adapted their domestic space to deal with seasonal changes, as obviously seen in stilt houses with high posts. The locals use space beneath their houses to carry on their daily chores most of the day, and they built multi shelves by fixing between a bay of columns to keep all their implements and fishery equipment during the flooding season. These shelves are adjustable at different levels depending on the water level of the flooding as can be seen in Figure 8 (left).
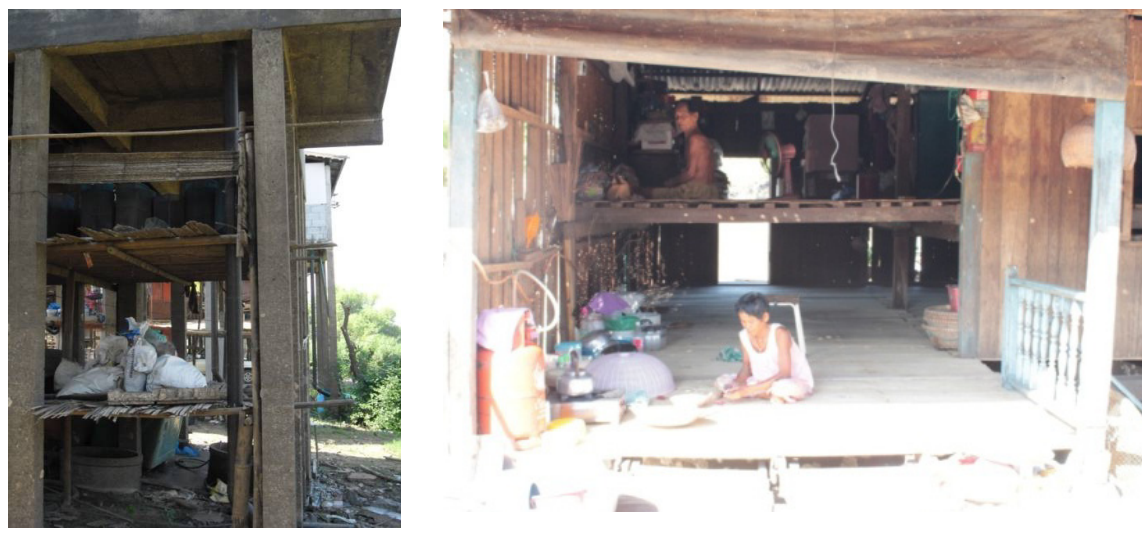

Figure 8: Left: elevated storage space. Right: split floor in a wooden stilt house located near the Yom River, Bangrakam. 
Moreover, some roofs function as storage rooms during the wet season. Interestingly, a few households created a temporary mezzanine on which they can sleep free from flooding (see Figure 8: Right). Another hybrid domestic space can be seen in a parking lot which was normally used during the dry season, while the space underneath the houses would be used for mooring canoes during the flooding.

\subsection{Aqua-cultural landscape}

Wet cultural landscape can be determined by various water-based elements which have been obviously seen during the flooding season. Aquatic plants are one of evidences which remain growing during the wet season. More importantly, water people live closely to water and have strong ties to the river. Moreover, they have certain skills related to water-based activities, such as swimming, rowing, as well as fishing chores. Obviously, canoes are other important aquatic vessels which people use to travel and to carry on their livelihood during the flooding season. Last but not least, various kinds of fishery tools are necessary methods for several households during the wet season to survive and generate incomes in the case of Bangrakam's settlement. All these water-based elements make it a unique cultural landscape.

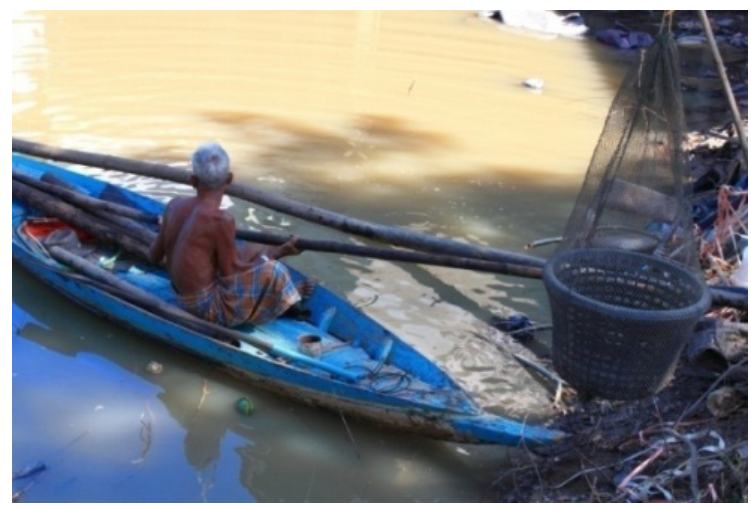

Figure 9: $\quad$ One of the locals who fishes for a living.

\subsection{Water-based livelihoods}

Bangrakam residents mainly make their living by growing rice and crops throughout the year; surprisingly, they can generate satisfactory income from fishing; particularly those who live along and nearby the river. People use bamboo strips, from local trees, to make fishing tools, fishing storage equipment, and fishing baskets, and other kind of basketry works, etc. They fish mainly for consumption purposes, and only for minor profit. 

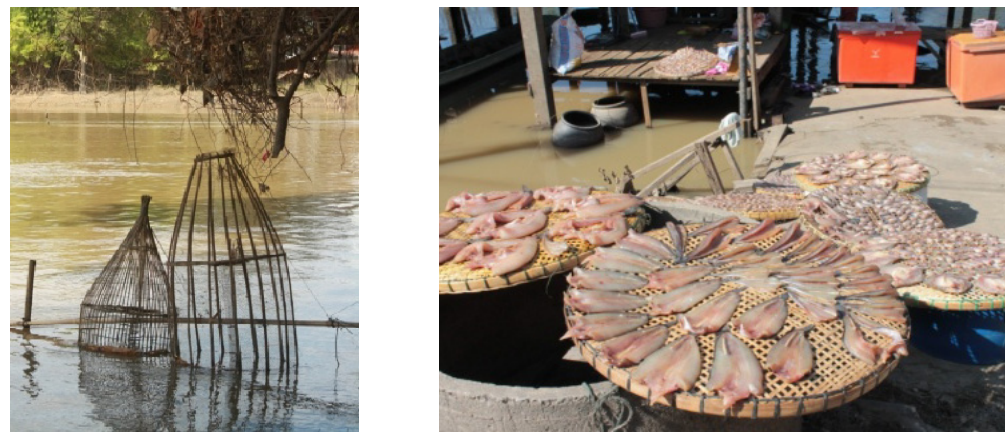

Figure 10: Left: fishery basketry. Right: dried fish.

It is important to note that flooding is a natural phenomenon in Bangrakam, as almost the whole district is inundated for a few months a year. Many residents stated that it is desirable being flooded for three months, as this a perfect time for breeding and allowing fish to grow enough so that they can get a better offer price. This is an illustration of human beings living with water in friendly ways without upsetting the other.

\section{Learning from Bangrakam case}

Living in the future world will become more difficult and complicated, due to a wide range of undesirable factors, such as climate changes, rising sea water levels, global warming, disasters, conflicts among humans, and other unexpected changes. Unfortunately, these issues occur across the world without any concrete boundary. The big flooding in 2011 has destroyed a large area across the country of Thailand and the water swallowed agricultural and industrial lands without any compromise. No excuse for Thais, as we keep developing our country to achieve a title of industrial matter with less regard to indigenous contexts. Rampant urbanisation is a case in point which has changed Thailand into a nicelooking modern country since 1950. A great number of cultivated lands crisscrossed by numerous canals have been replaced by non-farming areas and scores of roads. Consequently, a lot of natural drainage systems have been occupied by expansion of built-up areas resulting in undesirable flooding. Unfortunately, town planning has never succeeded in controlling urban sprawls in Thailand. It is a shame to say that almost all Thai planning has come from the Western ideas which mainly focus on managing land use, with less concern on traditional settlements, as these previous urban fabrics were dominated by water networks. The purpose of this paper is neither to make a new town planning for a better future nor to find a way to overcome flooding; however, this article aims to present another aspect of living with water in harmonious forms. Therefore, learning a successful story of Bangrakam may remind us to look backward to our good old days with water. However, water sanitation should be taken into account to insure healthy living environments. 


\section{Conclusion}

There are a few reasons making Bangrakam survive against flooding in friendly ways. Firstly, they can adapt their houses and domestic spaces to fit either dry or wet seasons. Secondly, the locals can also adjust their livelihoods to fit well and adapt to seasonal changes. Importantly, moreover, learning from indigenous wisdoms is an invaluable process in dealing with unexpected coming changes in the future. Lastly, adaptability in living in aquatic environments becomes a key ingredient for future context and challenging us to sustainability. My suggestion is that a proper town planning for Thailand should be carefully adapted and considered more on water land use supplementary to land use. It is important to realise that mere land use zoning has not been enough to avoid conflicts; on the other hand, aquatic zones should be taken into account in order to preserve natural drainage systems in order to avoid undesirable flooding in the future. Furthermore, learning from local wisdoms on how to live in harmony with water as human used to be is a helpful approach to try; however, water sanitation should be carefully considered for future resilience.

\section{References}

[1] The Bangrakam District Administration, the Development Plan of 2011 to 2013. 2011.

[2] Pittungnapoo, W. Wet Architecture, Phitsanulok Publications: Phitsanulok, 2011.

[3] Aerial map of Bangrakam. http://www.bangkokbiznews.com/home/detail /politics/life/20110906/408184. 